\author{
Vincent Adzahlie-Mensah \\ University of Education \\ Winneba, Ghana \\ Máiréad Dunne \\ Centre for International \\ Education \\ University of Sussex, UK
}

DOI: $h$ ttp://dx.doi. org/10.18820/2519593X/pie. v36i2.5

ISSN 0258-2236

e-ISSN 2519-593X

Perspectives in Education

2019 36(2): 44-60

(c) UVIUFS

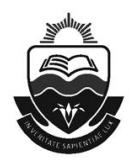

\section{Continuing in the shadows of colonialism: The educational experiences of the African Child in Ghana}

\begin{abstract}
In this paper, we draw on a recent ethnographic study in a rural primary school to illustrate the ways that vestiges of colonialism remain deeply imbricated in contemporary schooling in Ghana. In reference to the history of education, we use evidence from this study to argue that colonial constructions of the African child are reproduced within schooling. We highlight the significance of schooling for the production of learner subjectivities and point to the ways that the institution of schooling and its everyday life continue to echo and re-instantiate colonial constructions of the African child. Drawing on the voices and experiences of students and teachers we illustrate the ways that formal schooling continues to work to devalue indigenous knowledge, to regulate and discipline African children and produce their inferiorisation through their education. We specifically highlight the gender inflections in the institutional routines of schooling. Following a brief introduction to the historical context of education in Ghana, we outline the research study and then the theoretical position upon which our analysis is based. We develop the analysis along three major discursive themes starting with the formal institutional structures of the school, highlighting the ways its disciplinary boundaries structure age and gender relations. We then turn to the curriculum and pedagogic practices that shape student understandings of what constitutes legitimate knowledge and the processes of learning. In the final theme, we examine the language of instruction and the ways that this produces exclusions and vilifies indigenous languages and the cultures that are expressed through it. In the conclusion, we draw the key points together to reflect on the extent to which contemporary schooling in Ghana sustains the production of the African child framed in the colonial era. Finally, we suggest that the educational experience of students offers an important starting point for efforts in decolonizing the school and curriculum.
\end{abstract}

\section{Introduction}

The modern school system across Africa has its origins in colonialism. The dominant features - educational institutions, curriculum knowledge practices and language of instruction in schools - all may be directly traced to the colonial institutional structure. The discourses of the colonial education system and the vilified representations of the African child within it construct a politics of educational exclusion. The promotion of Western knowledge (including language and value systems) and the production of 
colonised citizenship work to degrade and exclude indigenous knowledges and identities with untold consequences on black populations that are still felt in the 21st century. Many scholars have described the modern institution of schooling in Africa as a significant channel for the violating, racialised colonial ideologies of distinction and superiority (Macedo, 1999; Dei \& Asgharzadeh, 2001; London, 2002; Harber, 2004). Specifically, the colonial school structures and practices are seen as perpetrating western dominance, alienating people from their cultural knowledge, producing strong gender hierarchies and creating a desire for very limited or non-existent modern sector jobs and western goods (Mazrui, 1978; Kuepie, et al., 2006; Adjei, 2007; Lugones, 2007; Leach, 2012).

Fundamental to justifications of the inequalities perpetrated through the colonial school system were representations of the African child. For example, Luggard (1922:217) depicted the African child as a "nude savage" acting with "inaccessible fastness of a cannibal" and in need of the "formation of character". Within that colonial logic, violent practices including racial segregation, exemplified explicitly in apartheid South Africa, passed as a way of moulding behaviour and producing "character". Indeed, the historical explorations of several researchers show that schools were constructed as extremely coercive and violent places (Shipman, 1971; Green, 1990; Adams, 1991; Harber, 2004) Further, Shute (1992:7) specifically argues that, from its colonial roots, "schools have not necessarily much to do with education... they were mainly institutions of control" that promoted the colonial agenda. An abundant literature confirms the way that in colonial interests, schools were initially structured to produce citizen workers for European merchant houses and later transformed to provide education that was aimed at creating a consumer taste for European goods, and to instantiate colonial practices as the gold standard (Graham, 1971; Macedo, 1999; London, 2002; Dei, 2004).

Formal schooling in Ghana is an "intellectual borrowing from Europe" (Sanjinés, 2007:300). It started with a Portuguese castle school at Elmina Castle around 1529 (Amedahe \& Chandramohan, 2009; Salifu \& Agbenyega, 2012) that operated racial exclusion by admitting mullatoes: children born to Ghanaian mothers by European fathers (Graham, 1971). The British colonial administration passed the first Education Ordinance in 1852 (Bening, 1990; GES, 2001) and Christian missionaries expanded schooling mainly to "serve the primary needs of evangelism" (Amedahe \& Chandramohan, 2009:8). At independence, only $6.6 \%$ of the population of Ghanaian school-aged children were in school. The nationalist government of Nkrumah implemented an Accelerated Development Plan (ADP) for Education in 1951 as "an aggressive programme of rapid expansion of education" (GES, 2001:7). The first Education Act (Act 87, 1961) prescribed 10 years of free compulsory elementary education for all children of school going age. The result was a rapid expansion of education between 1951 and 1966 with primary school numbers increasing from just over one thousand to over eight thousand and pupil numbers increasing from just over one hundred and fifty thousand to more than a million. The increases in access over time are indicated by national reports which most recently state a gross enrolment rate of $108 \%$ and net enrolment rate of $87.4 \%$ (MOE, 2017).

In the national context of mass access to schooling, in this paper we draw on an ethnographic case study to explore the ways that the colonial canon remains instantiated in school and integral to the production of the African children in the contemporary post-colonial context of Ghana. Our interests are in working at the micro-level to explore the daily life of schools as the crucible in which young Ghanaians are positioned and position themselves as they frame their identities. More specifically, we explore the operation of power within the 
structures and practices of schooling, the techniques of control and the responses of African children to the social relations of their schooling. In the next section, we outline the research study with a brief description of the case study school, our methodological approach and methods. We then turn to an outline of our theoretical position in advance of an analysis presented in three sections. These include the formal institutional structures of the school; curriculum and pedagogic practice and, lastly, the language of instruction. In each of these sections we trace the contours of coloniality and its sustained work in the framing the African child in schools. We conclude with a brief consideration of the implications for decolonizing the school and curriculum.

\section{The research}

\section{Methodology and methods}

The research drawn upon in this paper was institutional ethnographic case study of a Ghanaian primary school. We used a largely qualitative approach to generate detailed descriptions of the case and its context (Flick, 2006:230). Our interests were in exploring the institutionalisation of daily practices in school structures, rules and social relations and the ways these framed student subjectivities. To enable a holistic analysis of institutional rituals, repertoires and relationships we reviewed policy texts and then employed a combination of immersion and observation 'from within' and in-depth interviewing. The main data collection methods used were interviews, document analysis and observations.

The main school policy texts analysed were the Head teachers handbook and the Unified Code of Discipline for Basic Education Schools produced by the Ghana Education Service. We interacted with students and teachers in the case study school, observing activities as they unfolded and interviewing the school members. We used non-participant observation and conducted both episodic and in-depth interviews as we explored school practices and the ways these were embedded in institutional rules; how knowledge was socially organized and the wider social and relational complexities (Smith, 2005). These methods ensured the documents, events and experiences were brought under ethnographic scrutiny.

In the wider study, our interests were in locating the local context of the school in broader questions about the reach of national policy, and policy interpretations at local authority and school level. Using critical discourse analysis our analysis included a consideration of where the policy came from as well as what it is intended to achieve at the local level. This approach enabled us to derive data from well beyond the physical limits of the institution as well as focus on stories from the students as a means to include the "perspectives of people located distinctively in the institutional processes" (Smith, 2005:34). Through our in-depth examination of the various texts and especially of students' talk, we constructed meaning from their accounts in the context of regimes of patterned textual and social 'realities' of their lives in school (Campbell \& Gregor, 2002).

\section{The case study}

The school was a hard-to-reach rural primary school that comprised twelve teachers, including the head teacher and 253 students. With a gender parity index (GPI) of 1.2, there were more female (136) than males (117) students. Similarly there were more females (8), including the head teacher, than male (4) teachers. But unlike many rural schools in Ghana, the majority $(66 \%)$ of teachers were trained professionals. Five females and three males were trained and 
three females and one male were untrained. A prefect system, an enduring feature of British public schools, operated in the school. Students handpicked by teachers were appointed and their primary function was to assist teachers and monitor their peers. This produced a hierarchy within the student body.

Consistent with Ghana's free compulsory universal basic education programme, students were not required to pay tuition fees and the government was expected to provide textbooks and other teaching and learning materials. The main school policy texts were the Headteachers' handbook and the Unified Code of Discipline for Basic Education Schools produced by the Ghana Education Service. These nationally constituted texts defined the institutional order and power relations within the school. Every activity in the school was regulated by the timetable that detailed activities and subjects that teachers were supposed to teach each day, and the times allocated to each activity. Indeed, the dominant institutional culture of the school was framed by regulatory practices within the bureaucratic administration of the school including the timetable, the prefect system, rituals like the school assembly as well as other school rules and embedded practices.

The school provided the central context for the research. Policy texts, observation in classrooms and across the school, teacher interactions and interviews that were more formal all took place alongside pupil focused data collection. Beyond non-participant observation of students in a range of in-school scenarios, a group of fifteen students was purposively selected from Primary Classes 4, 5 and 6 (aged between 9 and 12 years) to comprise a critical case sample. Student in these grades were selected because Ghanaian education sector reports consistently identify that dropout rates are more pronounced in these grades and previous research findings conclude that students in these grades most frequently describe school as either "uninteresting or useless" (Pryor \& Ampiah, 2003; Akyeampong, et al., 2007:43). Five students were selected from each of the three grades and together the critical case sample comprised seven (7) males and eight (8) females. Ethical guidelines informed research procedures and interactions throughout the case study.

\section{Our theoretical starting points}

The focal point in this paper concerns the work of education in (re-) producing young Ghanaian subjectivities. Our interest was on the experiences of young African children within a Ghanaian primary school and the ways this shaped the production of their identities. The formal structure of the school as an institution, its daily routines and the social relations between school members were vital to these processes. As Foucault clearly articulates:

Take, for example, an educational institution: the disposal of its space, the meticulous regulations which govern its internal life, the different activities which are organized there, the diverse persons who live there or meet one another, each with his [sic] own function, his [sic] well-defined character-all these things constitute a block of capacity-communication-power. The activity which ensures apprenticeship and the acquisition of aptitudes or types of behaviour is developed there by means of a whole ensemble of regulated communications (lessons, questions and answers, orders, exhortations, coded signs of obedience, differentiation marks of the "value" of each person and of the levels of knowledge) and by the means of a whole series of power processes (en-closure, surveillance, reward and punishment, the pyramidal hierarchy)" (Foucault, 1982: 218-219). 
The processes of discipline and normalisation within schools were central to our exploration, however, as others have pointed out, analyses of schooling in former colonies is not productive "unless the legacies of colonialism are examined" (Viruru, 2005:10). With necessary interests in the colonial roots of schooling in Africa, a critical anti-colonial discursive framework (CADF) informed our analysis. CADF theorists underline the importance of formal schooling in governmentality and in colonial contexts to the "need to control populations in those colonies" (Harber, 2004:71). Importantly here is the observation that, even in the post-colonial context, schools as institutions of control have "proved impervious to change" (Harber, 2004:71).

Using CADF in the study of schooling draws attention to several inter-related sets of questions that include those about institutional practices and social relations; knowledge (re-)production and the implications of both for social identities (Dei \& Asgharzadeh, 2001; Dei, 2004; Smith, 2005; Mignolo, 2007). Locating these historically also provides the potential to initiate "radical rethinking of knowledge and social identities authored and authorized by colonialism" (Prakash, 1994:1475). Highlighting a persisting "vocabulary of power" associated with colonialism and "located within traditions of western rationality" (Rizvi et al., 2006:251) makes evident the ways these work to marginalise indigenous knowledges in the school curriculum (Dei, 2004; Viruru, 2005).

In our analysis of the institution of schooling in Ghana and its work on framing the African child in this context, we turn to the intertwined theorisations expressed as the coloniality of power and coloniality of knowledge (Quijano, 2000; Sanjinés, 2007). Coloniality of power refers to the ways ideas of "race" were produced and used by colonial powers to establish and naturalise relations of superiority and inferiority (Quijano, 2000; Smith, 2005; Mbembe, 2017). Further, these hierarchical orders are instantiated in the fabric of modern schooling which confers value or position on certain people while disenfranchising others (Smith, 2005). Discursive superiority / inferiority is integral to several discursive dyads including colonisercolonised; European-African; white-black, and similarly in the historic European positioning of women as inferior in the male-female binary (Lugones, 2007, Oyewumi, 1997). The persistence of these discursive social orders may be illustrated by the ways that schools, in post-colonial contexts, co-opt authoritative structures (e.g. timetables, age hierarchies, standardisations, assessment and rules of discipline including bodily comportment) that are every bit as oppressive as during colonial rule (Molteno et al., 2000; London, 2002).

Coloniality of knowledge refers specifically to an epistemic process of privileging some knowledge as more valid for development (Sanjinés, 2007). The promotion of education as a catalyst for economic development and modernity is reflected in school curriculum and its valorisation of particular knowledges. The prescribed curriculum produces an epistemic hierarchy that legitimates and privileges Western knowledge and a foreign, European language of instruction. This is a wholesale disparagement and disregard of indigenous knowledges and traditions in ex-colonies, in favour of colonial interests that continue to dominate global agendas (Adjei, 2007). From our CADF perspective curriculum analysis must concern:

not only what knowledge is important but also whose knowledge is important in the curricula, what and whose interests such knowledge serves, and how the curriculum and pedagogy serve (or do not serve) differing interests (Cohen et al., 2007:31).

The prescriptions of the school curriculum are a major vector in the coloniality of knowledge. With very limited reform, the curriculum works to reproduce and valorise colonial knowledge 
and perpetrate the epistemic violence in which indigenous knowledges are persistently devalued (Smith, 2005; Mignolo, 2007). In schools, questions of epistemology do not refer simply to what subjects are on the curriculum, but also about the 'how' of learning. Pedagogy is central to the framing of epistemological relations such that, interactions between and among teachers and students stand at the intersection of the coloniality of knowledge and of power. Our use of CADF here allows us to trace the discursive production of the 'African child' in post-colonial Ghana as we explore the ways pedagogical relations are framed by institutional practices of regulation and discipline and imbricated with gender (see Dunne et al., 2005; Lugones, 2008).

In the analysis that follows, we explore the disciplinary structures, curriculum, pedagogy and valorised knowledges of schooling predominantly through the perspectives of the students. Through this we trace the continuities in the education system from colonial to postcolonial times exploring the extent to which in Ghana today the subjectivities of young people remain haunted by the hierarchical framings of the African child in the racist and gendered colonial era.

\section{School structures and social relations}

We begin our analysis in this section in a discussion of the organisational structures of the school that have been shaped by school policy and practices. Together these establish institutional authority structures that define the social and academic status of students and set the norms and boundaries of interaction within the school (Smith, 2005). Ethnographic style observations of the daily life of the school, in the class and school compound, provided insights into the rules, regulation and discipline that constructed the social order of the school. In concert with other school ethnographies in Ghana (see for example, Dunne et al., 2005; Dunne and Ananga, 2013) in the case study, age and gender structures shaped the hierarchical social relations within the school.

Age relations between teachers and students are fundamental structure of schooling sustained since the colonial period. This age-authority structure is the basis for the spatial organisation of the school and operates among students and teachers alike. The spatial and temporal organisation of the school, for example through the timetable, is an important technology through which students are put under surveillance, observed and disciplined. The daily assembly or morning inspection parade is an example of an organisational structure with specific spatial and temporal regulations. This entailed the whole school lining-up militarystyle in the school compound and responding without hesitation to drills and instructions from the teacher. Those who failed to comply quickly and exactly to the commands were flogged with canes.

As with other practices derived from colonial times, gendered assumptions and divisions infused the morning parade. Although students were called to line in height order, shortest in front, girls were always at the front of each line with shortest boy following the tallest girl. Gender clearly dominated height as an organising principle even though it was a cause of considerable discomfort for both female and male students:

Sir, I am short and I can't see if I stand behind the girls. When they say "stretch your arms" my arms will pain me because my hand can't reach the tall girls' shoulder. (Male Student) 
How can you say "shortest in front" and then the tall girl will be in front of the shortest boy? I don't know why because the short boys cannot see anything. I think they suffer. Sometimes when they say 'straighten up your lines' or when they say 'arms forward stretched' then you see that the short boys are suffering. (Female Student)

The intersection of age and gender within the school instantiated gender differences and hierarchies. Other researchers describe such gendered social relations as an artefact of colonialism (Oyewùmí, 1997; Lugones, 2007). Specifically, Oyewùmí (1997) describes the gender dynamics in Africa as "the emergence of women as an identifiable category, defined by their anatomy and subordinated to men in all situations" and significantly as "one of the very first accomplishments of the colonial state" (p. 123-125). Similarly, Lugones (2008:8) claims that sex-gender categories were introduced in colonised societies "by the West as a tool of domination that designates two binarily opposed and hierarchical social categories". As such colonisation is a twofold process of "inferiorization and gender subordination" where "the exclusion of women" became natural and immutable (Oyewùmí, 1997:123). The strong and sustained resonances with the social dynamics of schooling suggest it is important to recognise the historical construction of a gendered African child.

Consistent with other school-based research, observations of the daily routines in the case study school illustrated the ways that the formal and informal curriculum produced and regulated gendered practices in terms of modes of dressing, school tasks, peer and teacher interactions and institutional posts (e.g. prefects) (Avotri et al., 2000; Dunne et al., 2005; Dunne et al, 2010; Dunne \&Adzahlie-Mensah, 2016; Akyeampong \& Adzahlie-Mensah, 2018). Taken together these studies describe mundane gender surveillance and control within schools that produce female inferiorisation, a male dominated gender hierarchy and institutionalised female subordination.

Within the case study school, all students were required to line-up, sit in class and respond without comment or complaint to teachers according to a hierarchical age/gender order. The disciplinary regime within the school including the ever-present threat of severe corporal punishment underscored a strong social hierarchy that positioned students as powerless, mute and lowest in the pecking order. The students elaborated their institutional positioning in the following:

Sir, if you come to school the teacher can even slap you ... We are nobodies.... (Female Student)

In this school, the students don't matter... even the prefects (Male Student)

The teachers think we don't know anything. (Female Student)

Sir, I am a prefect, but I don't think the teachers believe I know anything. (Female Student Prefect)

If you come to school, you know you are nobody. They say, I am the senior prefect but I cannot say anything... We just do what they say (Male Student Prefect)

Clearly, the students did not see themselves as complete members of the school. As Agbenyega and Klibthong (2011:406) noted in reference to early years education in Ghana, they viewed themselves as 'colonized bodies' treated as being nobodies (Dei, 2004; Rizvi et al., 2006, Adzahlie-Mensah, 2014). As colonized subjects, they were not regarded as 
full human beings and were denied rights of participation as full members of the institution. The denial of rights included the 'inability' to challenge their physical violation in school. Students were powerless and unable to speak back to the relations of domination into which they had become inserted in school. They were not involved in decision-making and largely did what they were instructed to do by the teachers. These modes of interaction bespeak the way that students were inserted into binary power relations of violent "masculine" authoritarianism connoted in being a teacher and a 'feminine' submissiveness of being student. Students' in their self-positioning as "nobodies" articulated the dehumanising relational dynamics within school and its deeply felt effects were elaborated in discussions:

We are not allowed to talk in the classroom. But it is impossible for a human being to be among a group of people in the same class for the whole day and not talk... How can it be possible that people will be in class and not talk at all? Me, Sir, I am only here in this school because my mother will not allow me to stop school now. But these rules are just bad! (Male Student)

Observations during the study consistently indicated minimal dialogue between teachers and students and certainly confirmed the claims made by students in interviews that they could not challenge the authority of teachers. The restrictions on verbal space and simple talk illustrate how students are "caught up in a system of constraints ... obligations and prohibitions", which work on the students' body "to imprison it, to make it work, it is in order to deprive the individual of a liberty that is regarded both as a right and as a property" (Foucault, 1977:11). The silencing exposes techniques in the social control of students within the institution that work to produce passive, politically docile and conformist citizens despite the wider rhetorical claims for empowerment and the progressive potential of formal education. (Adzahlie-Mensah, 2014; Dunne \& Adzahlie-Mensah, 2016). Indeed, we are reminded by Foucault of the operation of power within institution life and in this case its deep penetrating influence on the framing of student subjectivities:

But in thinking of the mechanisms of power, I am thinking rather of its capillary form of existence, the point where power reaches the very grain of individuals, touches their bodies and inserts itself into their actions and attitudes, their discourses, learning processes and everyday lives (Foucault 1980:39).

The final point of this section refers back to the organisational hierarchy that places the head teacher and teachers respectively in positions of institutional power. Prefects occupy an important place in the institutional hierarchy in their function to support teachers and to enforce the institutional regime by disciplining other students. This intermediary authority position again was consistently gendered. Female prefects were subordinate to male prefects and they were less visible in the school. Teachers normally called on male prefects who largely acted as dominant inspectors supervising the performance of morning duties, writing names to report misbehaving students and commanding the morning assembly. Female students, on the other hand, were largely engaged in service tasks. They were sent to buy food, cleanup classrooms, guard the teachers' chairs or wash dishes. They provided water in bowls for teachers to wash their hands and cleaned the head teacher's office. The female section leaders were also active in engaging students in sweeping the compound and classrooms. These gender segregated prefect duties mimicked a domestic division of labour in which their work was differently valued in ways that sustained the male dominated social hierarchy in the school. As Oyewùmí (1997:123) points out "The very process by which females were categorized ... made them ineligible for leadership roles." 
In this section, we have explored the often taken for granted institutional framework of schools, highlighting the organisational structures and positions through which power is distributed and difference is instantiated. Referring back to the influence of colonialism, we have highlighted the sustained significance of institutional life to the student positionality and a normalisation of their inferiority. We have emphasised the ways that the social dynamics of age and gender re-construct particular versions of the gendered African child. In the next section, we turn to consider curriculum and classroom learning in the case study school.

\section{Curriculum and pedagogy}

In this section, we turn directly to the school curriculum, its knowledge content as well as teaching and learning. As Bernstein (2000) reminds us, however, the selection of curriculum subjects is an act of power that signals legitimate and valorised knowledge. The classification of 'sacred' curriculum knowledge at the same time produces a distinction from 'profane' knowledge that is excluded from the formal curriculum. In this case, the school curriculum followed the approved national prescriptions that are broadly similar to those in other ex-British colonies. With traces back to the colonial past, the approved primary school subjects included Creative Arts, English Language (including Library), Ghanaian Language (Fante), Mathematics, Natural Science, Religious and Moral Education (RME), Information and Communication Technology (ICT), and Physical Education (PE). In the upper primary Citizenship Education has been added. For each subject, the broad themes, topics, and specific objectives for each lesson are detailed in an approved teaching syllabus and associated student textbooks each subject area were also available.

The time allocation to each subject is an indicator of its relative importance within a hierarchy of curriculum knowledge. Within Ghanaian primary schools, English Language takes up over $25 \%$ of curriculum time per week compared to Ghanaian language, which is allocated around seven percent in the lower primary and just over nine percent in upper primary. In addition to this, English is the medium of instruction in school. This is a strong message about the hierarchical importance of English language and culture compared to Ghanaian language and culture. Further, the opportunities to express local culture through Creative Arts was restricted to 30 minutes (2.3\%) per week in the lower primary and 60 minutes $(4.9 \%)$ in the upper primary. Similarly, the potential space to discuss national identity, culture and citizenship values in Citizenship Education had no time allocation in the lower primary and only 30 minutes per week or $2.3 \%$ of all teaching time in upper primary. It is also interesting to note that Religious and Moral Education (RME) is taught and examined through mainly Christian perspectives that reflect the missionary roots of education in Africa.

Students clearly articulated their dissatisfaction with curriculum content and relevance:

Sir, we need subjects that help us to know our community! (Male Student)

Please Sir, some of the subjects are not useful to us. Why can't we learn about agriculture (Male Student)

In general terms, the legacies of colonialism and the inherited focus on modernisation haunt curriculum definition and delivery while at the same time occluding and traducing knowledges of the south. Post-colonial writers describe this as a form of cognitive violence perpetrated and sustained on those populations within ex-colonial nations (Quijano, 2000; Kanu, 2003; Sanjinés, 2007; Santos, 2014). In the case of Ghana, it appears that despite periodic reform 
the basic curriculum structure and emphasis still bears the traces of its colonial history that has not significantly interrupted the sustained epistemic damage. This is exemplified by the restricted legitimated space available in the formal curriculum for Ghanaian children to learn explicitly about the critical connections between their language, culture and identity (Fordham, 1998; Mereku et al., 2005; Bhat, 2008). In addition, as the extracts from students above suggest, the validation and dissemination of 'others' language and knowledge within schools simultaneously works to disenfranchise and disengage locally "relevant" knowledge and students (Quijano, 2000; Adjei, 2007).

The prevailing relations between teachers and students in the school, elaborated in the previous section, were reproduced within the classroom. Teachers were rather distant and formal in lessons and students were generally passive. Participation was limited to rote learning, repetition and chorus answers. To this extent, the teachers used transmission pedagogy to relay the received curriculum to students who were constructed as empty vessels, knowing nothing (Friere, 1993).

\begin{abstract}
Before you go to class you must be prepared to explain and explain because we all know the students do not know anything. You don't go there to ask them questions because you will waste your time. You just have to explain the things to them as much as you can. (Male Teacher)

If you want your teaching to be effective, just think carefully and plan how you can explain the content of the lesson to their [students'] understanding. Just go there and prepare to explain everything. (Female Teacher)
\end{abstract}

These teachers constructed themselves as the holders of legitimate knowledge and authoritarian transmitters of the formal, objectified and frozen knowledge of the curriculum (Smith, 2005). Without considering the possibilities of engaging students in different ways they asserted the centrality of the authoritative teacher in delivering the official curriculum. Through this 'poisonous pedagogy' (Miller, 1990) they positioned students as 'incompetents' - infantile, ignorant and incapable, producing "children as colonized bodies" (Agbenyega \& Klibthong, 2011:406), as passive, unquestioning and without critical agency (Giroux, 2004). Such images of students, of the Ghanaian child, are reminiscent of Luggard (1922) and bespeak the persistence of the curriculum positioning of teachers as the civilizers of students. The preoccupation with the delivery and consumption of received, archaic curriculum knowledge denied students the possibilities of being socially and intellectually engaged in knowledge construction in the classroom.

In a reproduction of the wider school gender regime, spatial arrangements in the classrooms were strongly gendered with a repeated pattern of girls at the front and boys at the back. This spatial positionings were symbolic in students' performances of femininity and masculinity and the discursive production of female inferiority. The location of the boys at the back behind girls in the classroom or in lines suggests a form of protection by the males of the "weak" females that worked to reassert female inferiority (Adzahlie-Mensah \& Eshun, 2017). Lugones (2007) highlights the way that the gendered process of colonization involved casting women in the colonies in the image of 'fragile and sexually passive' European women of the time. The projection of such idealised femininities also clearly has implications for gender and sexual dynamics and relations. (Nayak \& Kehily, 2008). The normalisation of gender segregation within schools, although not prescribed in policy, echoes the colonial institution of single sex schooling. Across West Africa Europeans set up single sex schools with gender 
differentiated curricula in which girls received an education that focused on domestic and 'home' skills (Leach, 2012). It is worth noting that the colonial tradition of single sex schooling is still sustained today in the high cost, high status, fee-paying secondary schools in Ghana.

Within the case study, the teachers, perhaps in the discursive construction of their superiority, tended to restrict any dialogue with the students or active classroom management of the social organisation of the class. So although they recognised that the gendered arrangements looked discriminatory, they did not consider it either relevant or significant enough to provoke their intervention. Both the inferiorisation of students and the normalisation of gender differences were nevertheless highly significant to the experiences and identities of Ghanaian students in school (Anamuah-Mensah et al., 2004; Dunne et al., 2005a; Mereku et al., 2005).

\section{Language of instruction}

In this section, we continue to focus on the curriculum but more specifically of English as a medium of instruction in schools. While English as subject takes up around one quarter curriculum time, its use as a medium for all curriculum knowledge is much more penetrating. Evidently, this is a legacy of British colonialism and an important vector of colonial power. Fanon (1967) describes language as an "arsenal of complexes that has been developed by the colonial environment" (p.23) and its institution in schools as "the colonial moment of epistemic, cultural ... violence" separating people from their language, which is a central constituent of their identities (1967:479). For Bhabha (2004) writing textbooks and school materials in English is a signifier of colonial cultural authority, which Glowacka and Boos (2002) describe as the effective silencing of a people - the "cutting of a tongue". In reference to South Africa, Painter (2010) points to the use of colonial language in the production of race and ethnicity used in practices of social segregation.

Nevertheless, the widespread imposition of a colonial European language as the medium of instruction within education has been sustained and despite policy reforms they remain a persistent and enduring feature of schooling across Africa. Books, curriculum materials, and teachers - student interactions are engaged with through a colonial language whether English, French or Portuguese. Further, within the educational systems of Anglophone West Africa, proficiency in English is key to educational success and progress. The power of English as the medium of instruction is integral to teaching, learning and examination and has come to symbolise 'good' education.

...some [parents] also think the school is not good if the children cannot speak good English (Female Teacher)

English is an international language so it helps to learn in it. It is not our language but we all have to use it because it is the approved language for teaching. The books are written in English. (Female Teacher)

The students, however, expressed frustration at the curriculum dominance of English:

Why should we learn in English? Why is it that only Fante teacher teach in Fante? (Female Student)

Everything is in English. The books are in English ... The teachers teach us in English. They tell you everything in English. Everything is English, English, English... Sir, we only speak Fante when Fante teacher comes to teach (Male Student) 
As a mode of communication and representation, language can never be neutral but rather it holds deep significance for culture, identity and thought (Ochs, 1993; Toohey, 2000; Bhat, 2008). It is in this sense that Glowacka and Boos (2002:295) describe the educational imposition of English as a "swallower of identities". Teachers were keenly aware of its implications,

I mean English is everything which is also not very good for our local languages that are 'dying'. But we all have to use it because it is the approved language for teaching (Female Teacher)

Emphasis on English only has 'killed' our languages because we all have a narrow idea that the children need good English to pass BECE. We do everything in English because the final exam questions are set in English. Sometimes you feel students don't get you when you teach but the concepts are in English and you need to teach it that way. (Female Teacher).

The use of English persists in Ghana despite research evidence on the beneficial effects on learning of using the first language in schools (Graham, 1971; Toohey, 2000; Seidu et al., 2008; Bhat, 2008). For students the majority of their school experience from class texts to teacherstudent interactions were in English pushing their indigenous language to the periphery of the curriculum landscape. For teachers with their better language skills, this provided another axis through which to accentuate the asymmetrical social relations of classroom, described in a previous section, to emphasise their superiority and authority. Within the case study school and classrooms, the inferiorisation of Ghanaian children was further demonstrated through punishments for speaking their indigenous language.

They [teachers] teach in English. Sir, sometimes we don't understand but you cannot ask. ... Only the Fante (local language) teacher teach in Fante (Female Student)

Sir, English is good but if you don't speak good English they will beat you. They will say you don't know anything. Everything is English, everything! We do worship in English, assembly everything... (Male Student)

For students with limited fluency, the centrality of English to educational experiences left them with reduced opportunities to participate and interact with their peers or teachers in the classroom. Being poor in English was not only to lack the skills of reading and writing, in a context of transmission pedagogy, it was also to feel powerless and dependent in much broader terms (Freire, 1972). There are direct negative effects on the quality of learning as Ghanaian children are left with limited space to think through concepts in their own language. In this way, English language proficiency constitutes the ideological edifice for practices of segregation, not only around learning and "ability", but also, as we suggested earlier, in producing the gender, ethnic and racial difference of the African Child.

English-only instruction denied students opportunities to participate fully in school activities and rendered their sociolinguistic existence invisible. The limitations on students' 'talk' represents the sustained imposition of colonial cultural authority fundamental in the subjectification of African children. Further, this process of linguistic colonisation radically uproots children from their ancestry (Esteva, 2004). It is in this sense that African children have always been "at the risk of being alienated from their environment, people, and culture" (Adjei, 2007:1048) and have even become 'misfits' in their own villages (Mazrui, 1978).

Finally, it is important to note that evidence from the case study school illustrated that students with better English language skills were appointed to positions within the institutional 
hierarchy as class captains and school prefects. This has the double effect of normalising the hierarchical structures of schooling and further underscoring the importance of proficiency in the colonial language. In addition, these prefects were given the power to monitor their peers at every level of task and activity and as such become a force for the educational exclusion.

\section{Concluding comments}

This paper draws critical attention to the way colonialism continues to cast a long shadow over the educational context in Ghana. Based on a recognition of the work of education in framing and producing student subjectivities, our analysis of ethnographic case study data illustrates the sustained influence of British colonialism on Ghanaian schools and children to date. We explored the data through three analytical foci, firstly, the formal institutional structures of the school, secondly the curriculum and pedagogic practices, and finally the language of instruction. By drawing on the voices and experiences of students and teachers as well as observational data in school and classrooms, we have illustrated the ways that schooling continues to echo and re-instantiate colonial constructions of the gendered African child.

The daily experiences of schooling produce an inferiorisation and silencing of Ghanaian students through age and gender relations. We specifically highlighted the sustained gender inflections in the institutional routines of schooling as integral to colonization processes. In addition, we illustrated that relations between teachers and students bear the hallmarks of authoritarian regulation. The absence of teacher-student dialogue left very limited public space for student self-expression. Student participation in the school was highly regulated and dominated by their compliant responses to directives from teachers and prefects both in and out of the classroom. The image of the Ghanaian student as a mute, empty vessel is reiterated by teachers and informs a rationale for their pedagogic practice. Compounded by a curriculum that valorises the knowledge and language of foreign others, the students come to understand and describe themselves as 'nobodies'. Significantly, we point to the constitution of legitimate, valued knowledge through the curriculum that excludes and vilifies indigenous knowledge, languages and cultures as well as students own experiences.

In this paper we have highlighted the contours of a colonial heritage that continues to (re-) produce the very definitions of what 'proper' education is. The normalization of specific colonial organizational and curriculum structures and practices, instantiated in the institutional fabric of the school, continue to circumscribe the production of the "African child". In this context, it would appear to us that efforts in decolonising education might usefully start with an engagement with the schooling experiences of the African child. The inclusion of their voices would open avenues through which local and national knowledge, languages and cultures could be drawn upon to occupy a legitimated and valorised space in the official curriculum. This could begin to address the epistemic violence as well as encourage participation and improve learning. The focus on the qualitative experiences of education in teaching and research will also offer an overdue counter to dominance of quantitative approaches in understanding both realms.

\section{References}

Adams, R. 1991. Protests by pupils: Empowerment, schooling and the state. London: Falmer Press

Adjei, P.B. 2007. Decolonising knowledge production: The pedagogic relevance of Gandhian Satyagraha to schooling and education in Ghana. Canadian Journal of Education, 30(4), 1046-1067. https://doi.org/10.2307/20466678 
Adzahlie-Mensah, 2014. Being nobodies: Student accounts of school regimes and learner identities. Unpublished doctoral Thesis. Brighton: University of Sussex.

Adzahlie-Mensah, V. \& Eshun, I. 2017. Inferiorisation: The human rights analysis of being a female in school. American Journal of Educational Science, 3(3), 19-26.

Agbenyega, J.S. \& Klibthong, S. 2011. Early childhood inclusion: A postcolonial analysis of pre-service teachers' professional development and pedagogy in Ghana. Contemporary Issues in Early Childhood, 12(4), 404-416. https://doi.org/10.2304/ciec.2011.12.4.403

Akyeampong, K. \& Adzahlie-Mensah, V. 2018. Recent trends in school social control in Sub-Saharan Africa. In J. Deakin, E. Taylor \& A. Kupchik (Eds.). The Palgrave handbook of school discipline, surveillance, and social control (pp.191-211). https://doi. org/10.1007/978-3-319-71559-9_10

Amedahe, F.K. \& Chandramohan, K. 2009. Ghana - Towards FCUBE. In L. Brown (Ed.). Maintaining universal primary education: Lessons from Commonwealth Africa. London: Commonwalth Secretariat.

Anamuah-Mensah, J., Mereku, D.K. \& Asabere-Ameyaw, A. 2004. Ghanaian junior secondary school students' achievement in mathematics and science: Results from Ghana's participation in the 2003 trends in international mathematics and science study. Accra: Ministry of Education Youth and Sports.

Avotri, R., Owusu-Darko, L., Eghan, H. \& Ocansey, S. 2000. Gender and primary schooling in Ghana. Research Report No. 37. Brighton: IDS/FAWE.

Bening, R.B. 1990. A history of education in northern Ghana 1909-1976. Accra: Ghana Universities Press.

Bernstein, B. 2000. Pedagogy, symbolic control and identity. London: Rowman \& Littlefield.

Bhabha, H.K. 2004. The location of culture. New York: Routledge.

Bhat, M.A. 2008. Language: The ultimate tool of social control. Interdisciplinary Journal of Linguistics, 1, 111-118.

Clarke, C., Gomez, J.L., Hammonds, E., Johnson, B. \& Powell. L. 1983. Conversations and questions: Black women on black women writers. Conditions. Nine, 3(3), 88-137.

Campbell, M. \& Gregor, F. 2002. Mapping the social: A primer in doing institutional ethnography. Aurora, On: Garamond Press.

Cohen, L. Manion, L. \& Morrison, K. 2007. Research methods in education. London: Routledge. https://doi.org/10.4324/9780203029053

Dei, G.J.S. \& Asgharzadeh, A. 2001. The power of social theory: The anti-colonial discursive framework. Journal of Educational Thought, 35(3), 297-323.

Dei, G.J.S. 2004. Schooling and education in Africa: The case of Ghana. Trenton: Africa World Press, Inc.

Dunne, M., Leach, F., Chilisa, B., Maundeni, T., Tabulawa, R., Kutor, N., Forde, L. \& Asamoah, A. 2005. Gendered school experiences: The impacts on retention and achievement in Botswana and Ghana. London: DFID. 
Dunne, M., Bosumtwi-Sam, C., Sabates, R. \& Owusu. A. 2010. Bullying and school attendance: A case study of senior high school students in Ghana. Create pathways to access. Research Monograph No. 41.

Dunne, M. \& Ananga, D. E. 2013. Dropping out: Identity conflict in and out of school in Ghana. International Journal of Educational Development, 33(2), 196-205. https://doi.org/10.1016/j. ijedudev.2012.04.005

Dunne, M. and Adzahlie-Mensah, V. 2016. Subordinate subjects: The work of the hidden curriculum in post-colonial Ghana. In D. Wyse, L. Haywood, \& J. Pandya (Eds.). The Sage handbook of curriculum, pedagogy and assessment (pp.216-230). London: Sage. https://doi. org/10.4135/9781473921405.n14

Esteva, G. 2004. "Back from the future" - Notes for the presentation in schooling and education: A symposium with friends of Ivan Illich organized by TALC New Vision, Milwaukee, October 9, 2004.

Fanon, F. 1967. Black skin, white masks. New York: Grove Press.

Flick, U. 2006. An introduction to qualitative research. London: Sage.

Fordham, S. 1998, Speaking standard English from nine to three: Language as guerilla warfare at Capital High. In S. Hoyle \& C.T. Adger (Eds.). Kids talk: Strategic language use in later childhood. New York: Oxford University Press.

Foucault, M. 1977. Discipline and punish: The birth of the prison. London: Penguin.

Foucault, M. 1980. "On governmentality”. In C. Gordon (Ed.). Power/Knowledge. London: Harvester Press.

Foucault, M. 1982. The subject and power. In H. Dreyfus \& P. Rabinow (Eds.). Michel Foucault: beyond structuralism and hermeneutics, (pp.208-226). London: Harvester Wheatheaf.

Freire, P. 1972. Pedagogy of the oppressed. London: Sheed and Ward

GES 2001. Report of the study on the constitutional and legal framework for the right to pretertiary education in Ghana. Accra: MOESS/GES.

Giroux, H.A. 2004. Cultural studies and the politics of public pedagogy: Making the political more pedagogical. Parallax, 10(2), 73-89. https://doi.org/10.1080/1353464042000208530

Glowacka, D. \& Boos, S. 2002. Between ethics and aesthetics: Crossing the Boundaries (Suny Series in Aesthetics and the Philosophy of Art). New York: State University of New York Press.

Graham, C.K. 1971. The history of education in Ghana from the earliest times to the declaration of independence. Oxo: CASS.

Green, A. 1990. Education and state formation. London: Macmillan.

Harber, C. 2004. Schooling as violence: How schools harm pupils and societies. Falmer: Routledge. https://doi.org/10.4324/9780203488423

Kanu, Y. 2003. Curriculum as cultural practice: Postcolonial imagination. Journal of the Canadian Association for Curriculum Studies, 1(1), 67-81.

Kuepie, M., Nordman, C.J., \& Roubaud, F. 2006. Education and labour market outcomes in sub-Saharan West Africa. Paris: DIAL. 
Leach, F. 2012. Schooling of girls in nineteenth-century West Africa. History of Education, 42(2), 133-153. https://doi.org/10.1080/0046760X.2011.582048

London, N. 2002. Curriculum convergence: An ethno-historical investigation into schooling in Trinidad and Tobago. Comparative Education, 38(1), 53-72. https://doi. org/10.1080/03050060120103856

Luggard, F.D. 1922. The dual mandate in British tropical Africa. London: Blackwood \& Sons.

Lugones, M. 2007. Heterosexualism and the colonial/modern gender system. Hypatia, 22(1), 186-209.

Macedo, D. 1999. Decolonizing indigenous knowledge. In L. Semali, \& J.L. Kincheloe, (Eds.). What is indigenous knowledge: Voices from the academy. New York and London: Falmer Press.

Mazrui, A.A. 1978. Political values and the educated class in Africa. Berkeley: University of California Press.

Mbembe, A. 2017. A critique of Black reason. Durham, NC: Duke University Press. https://doi. org/10.1215/9780822373230

Mereku, K.D., Amedahe, F.K., Etsey, K., Adu, J., Acquaye, E., Synder, W., Moore A. \& Long, B. 2005. Opportunity to learn: English and mathematics in Ghanaian primary schools. Accra: CRDD.

Mignolo, W. 2007. Coloniality of power and decolonial thinking - Introduction. Cultural Studies, 21(1), 155-167. https://doi.org/10.1080/09502380601162498

Miller, A. 1990. For your own good: Hidden cruelty in child rearing and the roots of violence. New York: Farrar, Straus \& Giroux.

MOE. 2017. National education sector annual review report. Accra, Ghana: MOE.

Molteno, M., Ogadhoh, K., Cain, E. \& Crumpton, B. 2000. Towards responsive schools: Supporting better schooling for disadvantaged children. London: DFID/Save the Children.

Nayak, A. \& Kehily, M.J. 2008. Gender, youth and culture: Young masculinities and femininities. London: Palgrave Macmillan. https://doi.org/10.1007/978-1-137-12214-8

Ochs, E. 1993. Constructing social identity: A language socialisation perspective. Research on Language \& Social Interaction, 26(30), 287-306. https://doi.org/10.1207/s15327973rlsi2603_3

Oyewùmí, O. 1997. The invention of women: Making an African sense of Western gender discourses. Minneapolis: University of Minnesota Press.

Painter, D. W. 2010. Tongue-tied: The politics of language, subjectivity and social psychology. Unpublished doctoral thesis. Pretoria: University of South Africa.

Prakash, G. 1994. Subaltern studies as postcolonial criticism. American Historical Review, 99, 1475-1490. https://doi.org/10.2307/2168385

Pryor, J. \& Ampiah, J. 2003. Understandings of education in an African village: The impact of ICTs. Education Series Research Report No. 52. London: DfID.

Quijano, A. 2000. Colonidad del Poder y classificacion social. Journal of World Systems Research, 5(2), 342-388. https://doi.org/10.5195/JWSR.2000.228 
Rizvi, F., Lingard, B. \& Lavia, J. 2006. Postcolonialism and education: Negotiating a contested terrain. Pedagogy, Culture \& Society, 14(3), 249-262. https://doi. org/10.1080/14681360600891852

Salifu, I. \& Agbenyega, J.S. 2012. Impact of discipline issues on school effectiveness: The views of some Ghanaian principals. MIER Journal of Educational Studies, Trends and Practices, 2(1), 50-65.

Sanjinés, J. 2007. The nation: An imagined community? Cultural Studies, 21(2-3), 295-308. https://doi.org/10.1080/09502380601162662

Santos \& Boaventura de Sousa. 2014. Epistemologies of the South. Justice against Epistemicide. London: Paradigm Publishers.

Seidu, A., Mereku, D.K., Avoke, M., Ekumah, E., Tamanja, E.M.J. \& Adzahlie-Mensah, V. 2008. Report on teacher capacity for local language instruction. Accra: EQUALL/National Literacy Task Force \& USAID.

Shipman, M. 1971. Education and modernisation. London: Faber.

Shute, C. 1992. Compulsory schooling disease. Nottingham: Education Heretics Press.

Smith, D.E. 2005. Institutional ethnography: A sociology for people. Toronto: Alta Mira Press.

Takaki, R.I. 1993. A different mirror: A history of multicultural America. New York: Back Bay Books.

Toohey, K. 2000. Learning English at school: Identity, social relations and classroom practice. Clevedon: Multilingual Matters.

Viruru, R. 2005. The impact of postcolonial theory on early childhood education. Journal of Education, 9-29.

White, D.G. 1985. Aren't I a woman? Female slaves in the plantation south. New York: W.W. Norton. 